\title{
Effects of Social Information on the Release and Expression of Gonadotropin-Inhibitory Hormone in Birds
}

\section{OPEN ACCESS}

Edited by:

T. John Wu,

Uniformed Services University of the Health Sciences, United States

Reviewed by:

Chad D. Foradori,

Auburn University, United States

Pierre J. Deviche,

Arizona State University,

United States

*Correspondence:

Yasuko Tobar

tobari@azabu-u.ac.jp

Specialty section:

This article was submitted to

Experimental Endocrinology,

a section of the journal

Frontiers in Endocrinology

Received: 04 December 2018

Accepted: 27 March 2019

Published: 24 April 2019

Citation:

Tobari Y and Tsutsui K (2019) Effects of Social Information on the Release

and Expression of

Gonadotropin-Inhibitory Hormone in Birds. Front. Endocrinol. 10:243. doi: 10.3389/fendo.2019.00243

\author{
Yasuko Tobari $^{{ }^{*}}$ and Kazuyoshi Tsutsui ${ }^{2}$ \\ ${ }^{1}$ Laboratory of Animal Genetics and Breeding, Department of Animal Science and Biotechnology, School of Veterinary \\ Medicine, Azabu University, Sagamihara, Japan, ${ }^{2}$ Laboratory of Integrative Brain Sciences, Department of Biology, \\ Waseda University, Tokyo, Japan
}

The social environment changes circulating hormone levels and associated behavior in animals. Although social information is perceived by sensory systems in the brain, and peripheral reproductive hormonal levels are regulated mainly by the hypothalamus-pituitary-gonadal (HPG) axis, the neurochemical systems that convey social information to the HPG axis were not well-understood until the 2000s. In recent years, a growing body of evidence has demonstrated that a neuropeptide localized in the hypothalamus, gonadotropin-inhibitory hormone $(\mathrm{GnlH})$, is responsive to social information. GnlH was first identified in the quail hypothalamo-hypophyseal system and named for its ability to inhibit gonadotropin secretion. Hypothalamic GnlH neurons have thus begun to be regarded as integrators, translating social information into changes in the levels of circulating gonadal hormones through the HPG axis. Here, we review current research investigating the responses of the $\mathrm{GnlH}$ neuronal systems to social status, offspring, and the presence/absence of conspecifics, and describe the neurochemical pathways linking visual perception of a potential mate to a rapid change in blood gonadotropin levels via the hypothalamus-pituitary axis in male birds.

\footnotetext{
Keywords: gonadotropin-inhibitory hormone, gonadotropin-releasing hormone-l, hypothalamus-pituitarygonadal axis, neuropeptide, noradrenaline, RFamide-related peptide
}

\section{INTRODUCTION}

Many environmental factors can influence reproductive physiology in animals. While photoperiodic changes can induce or suppress reproductive activity in some species, additional environmental signals, such as temperature, humidity, food availability, and the presence of conspecifics, are also important in fine-tuning the timing of breeding (1). Social animals receive specific signals from the presence of conspecifics, and these signals evoke changes in neuropeptide systems, appropriate behavioral, and physiological responses for breeding (2-5).

It is now understood that social interactions influence neuropeptide systems. Neurons in the bed nucleus of the stria terminalis, which produce the avian nonapeptide arginine vasotocin, are selectively responsive to social stimuli and promote preferences for larger flock sizes in gregarious finches (6-8). Numbers of activated parvocellular neurons expressing mesotocin, within the paraventricular nucleus are correlated with courtship frequency in adult male brown anoles (Anolis sagrei) (9). In male European starlings (Sturnus vulgaris), only males that acquire nesting sites display high rates of sexual and agonistic behavior. Neurotensin (NT) is a 
neuropeptide implicated in motivation. NT expression in the medial preoptic nucleus (POM) is positively associated with courtship behavior in male starlings (10). Meanwhile male starlings with nesting sites have lower kappa-opioid receptor (opkr1) expression in the POM, and opkr1 expression is negatively associated with courtship vocal behavior (11). These studies suggest neuropeptide responses to social interaction may be related to expression of social behaviors.

The courtship behavior of male birds is a good model for studying the neural mechanisms that provoke hormonal responses to specific cues from conspecifics. When viewing a female, male birds show rapid changes in blood androgen concentrations. This social modulation of the concentrations of blood androgens may be a mechanism for adjusting androgendependent behaviors to the current social environment (12).

Testicular androgen production and release are under the control of the hypothalamus-pituitary-gonadal (HPG) axis (13). The hypothalamic neuropeptide gonadotropin-inhibitory hormone $(\mathrm{GnIH})$ acts on the HPG axis. A growing body of research shows that hypothalamic $\mathrm{GnIH}$ neurons are responsive to social information. Therefore this hypothalamic neuropeptide is viewed as an integrator molecule that translates social environmental information into reproductive physiology (14). In this review, we summarize current research on the social modulation of the release and expression of $\mathrm{GnIH}$ in the brain, with particular reference to $\mathrm{GnIH}$ responses to conspecifics.

\section{HYPOTHALAMIC NEUROPEPTIDE-RELATED AVIAN REPRODUCTION}

Avian reproductive physiology and blood androgen concentrations are regulated by the HPG axis. Gonadotropinreleasing hormone-I (GnRH1) is an evolutionarily conserved decapeptide and the central neuroendocrine regulator of the HPG axis (15). In stimulatory conditions, GnRH1 is released from nerve axons in the median eminence (ME) of the hypothalamus, stimulating the production and release of luteinizing hormone (LH) and follicle-stimulating hormone from the anterior pituitary gland, which, in turn, regulate testicular and ovarian functions $(16,17)$. In addition, GnIH has been revealed to be a pathway for reproductive control (18-20). GnIH was first identified in the quail hypothalamo-hypophyseal system and named for its ability to inhibit gonadotropin secretion (21). GnIH may also decrease GnRH1 synthesis and release in birds, because $\mathrm{GnIH}$ neurons make contact with both GnRH1 cell bodies and their nerve terminals in house sparrows (Passer domesticus) and European starlings (22, 23). $\mathrm{GnIH}$ receptors have been identified in the chicken and quail pituitary $(24,25)$, and are also expressed in GnRH1 neurons in the starling brain (23). These findings suggest that, as well as acting on the pituitary gland, GnIH acts on GnRH1 neurons to inhibit gonadotropin release.

Social information is perceived by the brain via sensory systems. The information seems to converge on the hypothalamus and is then transduced into a reproductive endocrine response through the portal vessels to the adenohypophysis (26). In male ring doves (Streptopelia risoria), synthesis of GnRH1 mRNA, and protein in the preoptic area of the hypothalamus increases in response to a 1-2-h courtship interaction with a female (3), prior to an increase in blood LH levels (27). In female white-throated sparrows (Zonotrichia albicollis), hearing courtship songs for $42 \mathrm{~min}$ induces an increase in the expression of immediate early genes in the mediobasal hypothalamus, which is the avian brain region involved in the control of GnRH1 release and elevation of blood LH level (28).

Recent studies have indicated that avian $\mathrm{GnIH}$ neurons in the hypothalamus are influenced by environmental information, including photoperiod and stress (29-31). GnIH has begun to be regarded as a modulator of reproductive activity in response to the external and internal environment $(18-20,32)$. In the 2010s, some research groups began to examine changes in the activity of $\mathrm{GnIH}$ neurons of avian species following various social interactions.

\section{EFFECTS OF SOCIAL STATUS AND BREEDING CONDITION ON GnIH EXPRESSION}

European starlings are cavity nesters and exhibit biparental care, with males and females sharing incubation and provisioning duties. To examine whether social status can alter hypothalamic GnIH synthesis to modulate reproductive physiology in different stages of the breeding season, Calisi et al. (33) manipulated nesting opportunities for pairs of European starlings and examined changes in the hypothalamic GnIH synthesis in nest owners (winners) and floaters (losers). Nest owners had significantly lower numbers of GnIH-producing cells than floaters at the beginning of the breeding season, whereas the number of $\mathrm{GnIH}$-producing cells was greater in nest owners than in floaters in the middle of the breeding season. The number of GnRH1-producing cells and the levels of plasma testosterone and corticosterone did not vary with nest box ownership. Meanwhile only European starlings that acquire nesting sites display high rates of reproductive behaviors including sexual and agonistic behavior. Maney et al. (34) reported that GnRH2 enhances copulation solicitation in estrogen-implanted female whitecrowned sparrows (Zonotrichia leucophrys gambelii) exposed to the song of males. Centrally administered GnIH rapidly inhibited this reproductive behavior in estradiol-treated female sparrows (35). GnIH neurons terminate in the close proximity of $\mathrm{GnRH} 2$ neurons in the midbrain of sparrows and starlings $(22,23)$ and GnRH2 neurons express GnIH receptor mRNA in European starlings (23). In sum, these data suggest that hypothalamic GnIH neurons in starlings may modulate reproductive behaviors via direct actions on the GnRH2 system, without altering the activities of the HPG axis, in response to nest competition.

\section{EFFECTS OF OFFSPRING ON GnIH SYNTHESIS}

Calisi et al. (36) continued their investigations of environmental influence on GnIH-producing cells and examined the effects of reproductive stage on $\mathrm{GnIH}$ cell abundance in the hypothalamus 
of European starlings. They quantified the number of GnIHproducing cells in starlings prior to nesting, prior to incubation, at the beginning and end of incubation, and at the start of chick care. GnIH-producing cells were most abundant when birds first began to incubate their eggs, and when chicks hatched. The starlings' blood testosterone increased at the beginning of the breeding season and peaked during the nest-building and fertile period when males were defending nest boxes, attracting females, and guarding their mates. Testosterone gradually decreased during the parental stage to facilitate parental behaviors (37). These data suggest that the presence of eggs increases $\mathrm{GnIH}$ neuronal activity at the beginning of incubation, resulting in the suppression of circulating testosterone that stimulates a behavioral switch from aggressive and sexual behavior to parental behavior.

In addition to characterizing GnIH cell abundance over the reproductive cycle in starlings, Calisi et al. (36) removed eggs on Day 8 of incubation to examine how unpredictable events in their incubation phase could affect hypothalamic GnIH system. They expected a decrease in GnIH cell abundance would be most likely to facilitate reproductive activity in order to obtain new offspring. However, GnIH cell abundance increased as a result of egg removal. GnIH expression can increase in response to acute stress in seasonally breeding birds (30). Thus, in this case, perhaps an increase in $\mathrm{GnIH}$ neuronal activity after nest predation (egg removal) may stimulate parent birds to switch nest-site and this switch may be important for reproductive success of starlings.

\section{EFFECTS OF FEMALE CONSPECIFICS ON GnIH SYSTEMS IN MALES}

A longstanding goal of avian endocrine research has been to clarify how the social environment might change gonadotropin and androgen levels in birds. In Japanese quail (Coturnix japonica), sexually active males exhibit a transient decline in circulating testosterone when they recognize a female conspecific $(38,39)$, suppressing courtship vocalization and actively approaching her for copulation (5, 40-42). Using this interesting animal model, we investigated the neurochemical pathways leading from the visual perception of a female conspecific to a change in blood gonadotropin level in male Japanese quail. Male birds viewing a female had increased levels of GnIH mRNA expression in the paraventricular nucleus (PVN) of the hypothalamus, which was associated with a decrease in the blood LH level (43). Likewise, noradrenaline (NA) release increased rapidly in the male PVN immediately after viewing a female. The expression level of GnRH1 mRNA did not vary. Viewing a male conspecific did not increase the level of GnIH mRNA in male birds. In addition, we showed that NA application dose-dependently stimulated $\mathrm{GnIH}$ release from the diencephalic explants in vitro, and intracerebroventricular injection of NA reduced blood $\mathrm{LH}$ concentrations (43). GnIH neurons express the $\alpha 2 \mathrm{~A}$-adrenergic receptor subtype mRNA and receive noradrenergic innervation (43). Accordingly, these findings suggest that viewing a female conspecific provokes an increase in NA release in the PVN, which directly stimulates the release of $\mathrm{GnIH}$, resulting in the suppression of $\mathrm{LH}$ secretion from the pituitary in male quail. This NA-GnIH system is a novel neurochemical pathway through which the social milieu can rapidly influence reproductive physiology in birds.

\section{EFFECTS OF NA AND SOCIAL ISOLATION ON GnIH EXPRESSION}

We have shown that NA treatment stimulates $\mathrm{GnIH}$ release from diencephalic tissue blocks (43). However, at the time of that study, it was unknown whether noradrenergic transmission plays an important role in regulating $\mathrm{GnIH}$ gene expression in the brain. There are two groups of noradrenergic cells in the avian brain: the locus coeruleus (LoC) group and the lateral tegmental (LT) group, whose cells of origin are diffusely distributed in the caudal pons and rostral medulla (44-46). The quail hypothalamus receives dense noradrenergic innervation (44) and contains a high concentration of NA compared to other areas of the brain $(47,48)$. Ligand binding experiments and in situ hybridization revealed a high density of $\alpha 2 \mathrm{~A}-$ and $\alpha 2 \mathrm{C}$-adrenergic receptors in the $\operatorname{PVN}(43,49)$.

$N$-(2-chloroethyl)- $N$-ethyl-2-bromobenzylaminehydrochloride (DSP-4) causes a selective decrease in noradrenergic neuronal activity, with degeneration of the axon terminals of noradrenergic neurons originating from the $\operatorname{LoC}(50,51)$. In quail, DSP-4 decreases NA concentrations only in the hypothalamus (48). To evaluate the specific role of noradrenergic LoC neurons in regulating hypothalamic GnIH gene expression, we investigated the change in $\mathrm{GnIH}$ gene expression in the hypothalamus of male quail in response to the decrease in hypothalamic NA by DSP-4 treatment. Interestingly, decreasing hypothalamic NA levels had different effects on brain GnIH gene expression according to the social situation of male quail. Noradrenergic ablation with DSP-4 did not change GnIH gene expression in the brains of male quail housed in an aviary, where all birds had visual and auditory (but no tactile) contact with other male conspecifics (52) or were exposed to a sexually active female (unpublished data). To remove the effect of conspecifics, after lowering diencephalic NA with DSP-4, we kept male quail alone in an empty room for $1 \mathrm{~h}$. Social isolation after lowering diencephalic NA concentration increased GnIH gene expression in the brains of male quail, suggesting that noradrenergic LoC neurons have an inhibitory effect on $\mathrm{GnIH}$ gene expression when male quail are alone (52). Meanwhile, DSP-4 treatment did not change the plasma LH level of male quail exposed to social isolation or a female for $1 \mathrm{~h}$ (unpublished data), suggesting that noradrenergic LoC neurons do not influence GnIH release.

Decreasing NA secretion pharmacologically influences $\mathrm{GnIH}$ gene expression differently in the brains of male quail housed in an aviary vs. socially isolated quail. In the aviary, quail were housed in adjacent individual cages. The quail in the aviary exhibited strongly intermittent pecking-like behavior toward male birds in neighboring cages. On the other hand, socially isolated quail exhibited locomotion (walk, run, jump) and resting (stand, sit) behaviors. Edens (53) 
indicated that aggressive pecking behavior is associated with increased brain NA concentrations in male quail housed in male pairs. Additionally, the $\mathrm{GnIH}$ concentration in the hypothalamus is associated with the frequency of sociosexual behaviors in male quail, including pecking (54). Visual and auditory information from male conspecifics, and peckinglike behavior toward them, may induce intermittent NA release from noradrenergic axon terminals unaffected by DSP-4. This intermittent NA release may have maintained extracellular NA levels in the PVN of quail in the aviary, resulting in no difference in hypothalamic $\mathrm{GnIH}$ gene expression between the DSP-4 treated and control birds in the aviary.

\section{EFFECTS OF SOCIAL RANK ON GnIH SYNTHESIS IN A EUSOCIAL MAMMAL}

Moving away from birds, the naked mole rat (NMR; Heterocephalus glaber) is a powerful model system for studying social reproductive repression, because NMRs are eusocial subterranean rodents and establish colonies wherein breeding is usually monopolized by only one female (the queen) and one to three males (dominants); the remaining colony members serve the colony as social subordinates and remain in a juvenile-like prepubescent state. Male and female subordinates are capable of transitioning to breeding status following the removal of dominants or separation from the colony. Dominants have high progesterone concentrations compared to colony-housed subordinates, and exhibit sexual behaviors. To clarify the role of RF-amide-related peptide-3 (RFRP-3, a mammalian ortholog of avian GnIH) in social regulation of puberty onset in NMRs, Peragine et al. (55) examined whether the social and reproductive hierarchy can alter hypothalamic RFRP-3 systems, and whether RFRP-3 can suppress sexual maturation in NMRs. Hypothalamic RFRP-3 expression was affected by reproductive status in NMRs. Subordinates had enhanced RFRP-3 immunoreactivity compared to dominants. Intracerebroventricular injection of RFRP-3 reduced the blood progesterone concentration and sexual interest in sexually active NMRs separated from the colony. These data suggest that hypothalamic RFRP-3 neurons in NMRs may serve as gatekeepers of puberty onset according to social rank.

\section{CONCLUSION AND FUTURE DIRECTIONS}

$\mathrm{GnIH}$ is a hypothalamic neuropeptide that suppresses and finely tunes reproduction in birds by directly modifying GnRH1 and gonadotrophin release. $\mathrm{GnIH}$ expression and synthesis are influenced by social status, breeding condition, and the presence of conspecifics. Female presence stimulates $\mathrm{GnIH}$ release via NA release in male birds. These findings suggest that $\mathrm{GnIH}$ neurons modulate the activities of the HPG axis in response to the social environment, as well as photoperiod and stress. Thus $\mathrm{GnIH}$ is a newly discovered integrator of environmental stimuli for reproduction; nevertheless, there remain unanswered questions about its roles and mechanisms of action.

First, does $\mathrm{GnIH}$ also play a role in rapid regulating social behaviors in response to social stimuli? Male quail increase $\mathrm{GnIH}$ neuronal activity when they recognize an attractive female conspecific. In addition, female presence suppresses instantly male courtship vocalization and promotes male approach for copulation. If $\mathrm{GnIH}$ can act directly within the brain to control reproductive behaviors $(35,54)$, activated $\mathrm{GnIH}$ neurons by female presence in male quail may modulate the neurol circuitry underlying social behaviors to change the pattern of courtship vocalization and social proximity behavior. The neural mechanisms of $\mathrm{GnIH}$ action in the brain regulating vocalization and social proximity behavior will be the focus of future studies.

A second question is whether NA is involved in regulating seasonal changes in GnIH function. Matt et al. (56) reported that the NA turnover rate was significantly lower in the preoptic area (the site of GnRH1 cell bodies) and the ME (the site of GnRH1 and GnIH terminals) of photorefractory white-crowned sparrows compared to photosensitive and photostimulated birds. In addition, NA is involved in the regulation of biosynthesis and release of melatonin (57), which is a potent regulator of $\mathrm{GnIH}$. These data suggest that NA also plays a role in regulating seasonal changes in $\mathrm{GnIH}$ synthesis and release. A third question is: What is the role of noradrenergic LT neurons in social modulation of $\mathrm{GnIH}$ neurons? Because the hypothalamus has rich noradrenergic innervation from the LT noradrenergic systems in rodents, it is likely that the avian hypothalamus is also richly innervated by noradrenergic LT neurons. Whether noradrenergic LT neurons affect $\mathrm{GnIH}$ neuronal activity remains unclear, and requires further investigation.

The role of $\mathrm{GnIH}$ in modulating the reproductive axis in vertebrates has been well-documented. However, studies on $\mathrm{GnIH}$ responses to social stimuli have only been conducted in a small number of species. Clarifying what kind of social information can affect $\mathrm{GnIH}$ neuronal activity, and the neural and molecular mechanisms by which social information affects $\mathrm{GnIH}$ neurons in many kinds of animals, would contribute not only to the field of reproductive endocrinology but also the neuroscience of sociality.

\section{AUTHOR CONTRIBUTIONS}

All authors listed have made a substantial, direct and intellectual contribution to the work, and approved it for publication.

\section{FUNDING}

The works in this review were supported at least partially by Grants-in-Aid for Private University research Branding project and Scientific Research from the Ministry of Education, Culture, Sports, Science, and Technology Japan (JP16K18585) and Scientific Research Grants from the Moritani Scholarship Foundation. 


\section{REFERENCES}

1. Wingfield JC. Environmental and endocrine control of reproduction: an ecological approach. In: Mikami S, Homma K, and Wada M. Avian Endocrinology. Tokyo: Japan Scientific Societies Press (1983). p. 265-288.

2. Ward MP, Schlossberg S. Conspecific attraction and the conservation of territorial songbirds. Conserv Biol. (2004) 18:519-25. doi: $10.1111 / j .1523-1739.2004 .00494 . x$

3. Mantei KE, Ramakrishnan S, Sharp PJ, Buntin JD. Courtship interactions stimulate rapid changes in gnrh synthesis in male ring doves. Horm Behav. (2008) 54:669-75. doi: 10.1016/j.yhbeh.2008.07.005

4. Maruska KP, Fernald RD. Social regulation of gene expression in the hypothalamic-pituitary-gonadal axis. Physiology. (2011) 26:412-23. doi: 10.1152/physiol.00032.2011

5. Tobari Y, Sato Y, Okanoya K. Hormonal responses to a potential mate in male birds. Adv Exp Med Biol. (2017) 1001:137-49. doi: 10.1007/978-981-10-3975-1_9

6. Goodson JL, Wang Y. Valence-sensitive neurons exhibit divergent functional profiles in gregarious and asocial species. Proc Natl Acad Sci USA. (2006) 103:17013-7. doi: 10.1073/pnas.0606278103

7. Goodson J, Rinaldi J, Kelly A. Vasotocin neurons in the bed nucleus of the stria terminalis preferentially process social information and exhibit properties that dichotomize courting and non-courting phenotypes. Horm Behav. (2009) 55:197-202. doi: 10.1016/j.yhbeh.2008.10.007

8. Kelly AM, Kingsbury MA, Hoffbuhr K, Schrock SE, Waxman B, Kabelik D, et al. Vasotocin neurons and septal $\mathrm{V}(1 \mathrm{a})$-like receptors potently modulate songbird flocking and responses to novelty. Horm Behav. (2011) 60:12-21. doi: 10.1016/j.yhbeh.2011.01.012

9. Kabelik D, Magruder DS. Involvement of different mesotocin (oxytocin homologue) populations in sexual and aggressive behaviours of the brown anole. Biol Lett. (2014) 10:20140566. doi: 10.1098/rsbl.2014.0566

10. Merullo DP, Cordes MA, Susan DeVries M, Stevenson SA, Riters LV. neurotensin neural mrna expression correlates with vocal communication and other highly-motivated social behaviors in male european starlings. Physiol Behav. (2015) 151:155-61. doi: 10.1016/j.physbeh.2015.07.019

11. Riters LV, Cordes MA, Stevenson SA. Prodynorphin and kappa opioid receptor mRNA expression in the brain relates to social status and behavior in male european starlings. Behav Brain Res. (2017) 320:37-47. doi: 10.1016/j.bbr.2016.11.050

12. Oliveira RF. Social behavior in context: hormonal modulation of behavioral plasticity and social competence. Integr Comp Biol. (2009) 49:423-40. doi: 10.1093/icb/icp055

13. Ottinger MA, Bakst MR. Endocrinology of the avian reproductive system. $J$ Avian Med Surg. (1995) 9:242-50.

14. Kriegsfeld LJ, Ubuka T, Bentley GE, Tsutsui K. Seasonal control of gonadotropin-inhibitory hormone $(\mathrm{GnIH})$ in birds and mammals. Front Neuroendocrinol. (2015) 37:65-75. doi: 10.1016/j.yfrne.2014.12.001

15. Millar RP, Lu ZL, Pawson AJ, Flanagan CA, Morgan K, Maudsley SR. Gonadotropin-releasing hormone receptors. Endocr Rev. (2004) 25:235-75. doi: 10.1210/er.2003-0002

16. Matsuo H, Baba Y, Nair RM, Arimura A, Schally AV. Structure of the porcine LH- and FSH-releasing hormone. I the proposed amino acid sequence. Biochem Biophys Res Commun. (1971) 43:1334-9.

17. Burgus R, Butcher M, Amoss M, Ling N, Monahan M, Rivier J, et al. Primary structure of the ovine hypothalamic luteinizing hormone-releasing factor (LRF). Proc Natl Acad Sci USA. (1972) 69:278-82.

18. Tsutsui K. A new key neurohormone controlling reproduction, gonadotropin-inhibitory hormone $(\mathrm{GnIH})$ : biosynthesis, mode of action and functional significance. Prog Neurobiol. (2009) 88:76-88. doi: 10.1016/j.pneurobio.2009.02.003

19. Tsutsui K, Bentley GE, Bedecarrats G, Osugi T, Ubuka T, Kriegsfeld LJ. Gonadotropin-inhibitory hormone $(\mathrm{GnIH})$ and its control of central and peripheral reproductive function. Front Neuroendocrinol. (2010) 31:284-95. doi: 10.1016/j.yfrne.2010.03.001

20. Tsutsui K, Bentley GE, Kriegsfeld LJ, Osugi T, Seong JY, Vaudry H. Discovery and evolutionary history of $\mathrm{GnIH}$ and kisspeptin: new key neuropeptides controlling reproduction. J Neuroendocrinol. (2010) 22:716-27. doi: $10.1111 / j .1365-2826.2010 .02018 . x$
21. Tsutsui K, Saigoh E, Ukena K, Teranishi H, Fujisawa Y, Kikuchi M, et al. A novel avian hypothalamic peptide inhibiting gonadotropin release. Biochem Biophys Res Commun. (2000) 275:661-7. doi: 10.1006/bbrc.2 000.3350

22. Bentley GE, Perfito N, Ukena K, Tsutsui K, Wingfield JC. Gonadotropininhibitory peptide in song sparrows (Melospiza melodia) in different reproductive conditions, and in house sparrows (Passer domesticus) relative to chicken-gonadotropin-releasing hormone. J Neuroendocrinol. (2003) 15:794-802. doi: 10.1046/j.1365-2826.2003.01062.x

23. Ubuka T, Kim S, Huang YC, Reid J, Jiang J, Osugi T, et al. Gonadotropininhibitory hormone neurons interact directly with gonadotropin-releasing hormone-I and -II neurons in European starling brain. Endocrinology. (2008) 149:268-78. doi: 10.1210/en.2007-0983

24. Ikemoto T, Park MK. Chicken RFamide-related peptide $(\mathrm{GnIH})$ and two distinct receptor subtypes: identification, molecular characterization, and evolutionary considerations. J Reprod Develop. (2005) 51:359-77. doi: $10.1262 /$ jrd.16087

25. Yin $\mathrm{H}$, Ukena K, Ubuka T, Tsutsui K. A novel G protein-coupled receptor for gonadotropin-inhibitory hormone in the Japanese quail (Coturnix japonica): identification, expression and binding activity. J Endocrinol. (2005) 184:25766. doi: $10.1677 /$ joe. 1.05926

26. Ball GF. The neural integration of environmental information by seasonally breeding birds. Amer Zool. (1993) 33:185-99.

27. Silver R, Goldsmith AR, Follett BK. Plasma luteinizing hormone in male ring doves during the breeding cycle. Gen. Comp Endocrinol. (1980) 42:19-24.

28. Maney DL, Goode CT, Lake JI, Lange HS, O’Brien S. Rapid neuroendocrine responses to auditory courtship signals. Endocrinology. (2007) 148:5614-23. doi: 10.1210/en.2007-0879

29. Ubuka T, Bentley GE, Ukena K, Wingfield JC, Tsutsui K. melatonin induces the expression of gonadotropin-inhibitory hormone in the avian brain. Proc Natl Acad Sci USA. (2005) 102:3052-7. doi: 10.1073/pnas.0403840102

30. Calisi RM, Rizzo NO, Bentley GE. Seasonal differences in hypothalamic EGR-1 and GnIH expression following capture-handling stress in house sparrows (Passer domesticus). Gen Comp Endocrinol. (2008) 157:283-7. doi: 10.1016/j.ygcen.2008.05.010

31. Chowdhury VS, Yamamoto K, Ubuka T, Bentley GE, Hattori A, Tsutsui K. Melatonin stimulates the release of gonadotropin-inhibitory hormone by the avian hypothalamus. Endocrinology. (2010) 151:271-80. doi: 10.1210/en.2009-0908

32. Parhar I, Ogawa S, Kitahashi T. RFamide peptides as mediators in environmental control of GnRH neurons. Prog Neurobiol. (2012) 98:176-96. doi: 10.1016/j.pneurobio.2012.05.011

33. Calisi RM, Diaz-Munoz SL, Wingfield JC, Bentley GE. Social and breeding status are associated with the expression of GnIH. Genes Brain Behav. (2011) 10:557-64. doi: 10.1111/j.1601-183X.2011.00693.x

34. Maney DL, Richardson RD, Wingfielda JC. Central administration of chicken gonadotropin-releasing hormone-II enhances courtship behavior in a female sparrow. Horm Behav. (1997) 32:11-8.

35. Bentley G, Jensen J, Kaur G, Wacker D, Tsutsui K, Wingfield J. Rapid inhibition of female sexual behavior by gonadotropin-inhibitory hormone (GnIH). Horm Behav. (2006) 49:550-5. doi: 10.1016/j.yhbeh.20 05.12.005

36. Calisi RM, Geraghty AC, Avila A, Kaufer D, Bentley GE, Wingfield JC. Patterns of hypothalamic GnIH change over the reproductive period in starlings and rats. Gen Comp Endocrinol. (2016) 237:140-6. doi: 10.1016/j.ygcen.2016.08.015

37. Pinxten R, de Ridder E, Arckens L, Darras VM, Eens M. Plasma testosterone levels of male european starlings (Sturnus vulgaris) during the breeding cycle and in relation to song and paternal care. Behaviour. (2007) 144:393-410. doi: $10.1163 / 156853907780756003$

38. Delville Y, Sulon J, Hendrick JC, Balthazart J. Effect of the presence of females on the pituitary-testicular activity in male japanese quail (Coturnix coturnix japonica). Gen Comp Endocrinol. (1984) 55:295-305.

39. Cornil CA, Stevenson TJ, Ball GF. Are rapid changes in gonadal testosterone release involved in the fast modulation of brain estrogen effects? Gen Comp Endocrinol. (2009) 163:298-305. doi: 10.1016/j.ygcen.2009.04.029

40. Domjan M, Nash S. Stimulus control of social behaviour in male japanese quail, Coturnix coturnix japonica. Anim Behav. (1988) 36:1006-15. 
41. Meddle SL, King VM, Follett BK, Wingfield JC, Ramenofsky M, Foidart A, et al. Copulation activates fos-like immunoreactivity in the male quail forebrain. Behav Brain Res. (1997) 85:143-59.

42. Charlier TD, Ball GF, Balthazart J. Sexual behavior activates the expression of the immediate early genes c-fos and Zenk (egr-1) in catecholaminergic neurons of male japanese quail. Neuroscience. (2005) 131:13-30. doi: 10.1016/j.neuroscience.2004.09.068

43. Tobari Y, Son YL, Ubuka T, Hasegawa Y, Tsutsui K. A new pathway mediating social effects on the endocrine system: female presence acting via norepinephrine release stimulates gonadotropin-inhibitory hormone in the paraventricular nucleus and suppresses luteinizing hormone in quail. $J$ Neurosci. (2014) 34:9803-11. doi: 10.1523/JNEUROSCI.3706-13.2014

44. Bailhache T, Balthazart J. The catecholaminergic system of the quail brain: immunocytochemical studies of dopamine $\beta$-hydroxylase and tyrosine hydroxylase. J Comp Neurol. (1993) 329:230-56. doi: 10.1002/cne.903290206

45. Moons L, D'Hondt E, Pijcke K, Vandesande F. Noradrenergic system in the chicken brain: immunocytochemical study with antibodies to noradrenaline and dopamine- $\beta$-hydroxylase. J Comp Neurol. (1995) 360:331-48.

46. Mello CV, Pinaud R, Ribeiro S. Noradrenergic system of the zebra finch brain: immunocytochemical study of dopamine- $\beta$-hydroxylase. J Comp Neurol. (1998) 400:207-28.

47. Ottinger MA, Balthazart J. Brain monoamines and sexual behavior in japanese quail: effects of castration and steroid replacement therapy. Behav Proc. (1987) 14:197-216.

48. Balthazart J, Libioulle J-M, Sante P. Stimulatory effects of the noradrenergic neurotoxin DSP4 on sexual behavior in male quail. Behav Proc. (1988) 17:27-44

49. Ball GF, Nock B, McEwen BS, Balthazart J. Distribution of alpha 2adrenergic receptors in the brain of the japanese quail as determined by quantitative autoradiography: implications for the control of sexually dimorphic reproductive processes. Brain Res. (1989) 491:68-79.

50. Waterman SA, Harding CF. Neurotoxic effects of DSP-4 on the central noradrenergic system in male zebra finches. Behav Brain Res. (2008) 188:271-80. doi: 10.1016/j.bbr.2007.11.004
51. Poirier C, Boumans T, Vellema M, De Groof G, Charlier TD, Verhoye $\mathrm{M}$, et al. own song selectivity in the songbird auditory pathway: suppression by norepinephrine. PLoS ONE. (2011) 6:e20131. doi: 10.1371/journal.pone.0020131

52. Tobari Y, Kansaku N, Tsutsui K. Noradrenergic modulation of gonadotrophin-inhibitory hormone gene expression in the brain of japanese quail. J. Neuroendocrinol. (2017) 29:e12503. doi: 10.1111/jn e. 12503

53. Edens FW. Agonistic behavior and neurochemistry in grouped japanese quail. Comp Biochem Physiol A Comp Physiol. (1987) 86:473-9.

54. Ubuka T, Haraguchi S, Tobari Y, Narihiro M, Ishikawa K, Hayashi $\mathrm{T}$, et al. Hypothalamic inhibition of socio-sexual behaviour by increasing neuroestrogen synthesis. Nat Commun. (2014) 5:3061. doi: $10.1038 /$ ncomms4061

55. Peragine DE, Pokarowski M, Mendoza-Viveros L, Swift-Gallant A, Cheng HM, Bentley GE, et al. RFamide-related peptide-3 (RFRP-3) suppresses sexual maturation in a eusocial mammal. Proc Natl Acad Sci USA. (2017) 114:120712. doi: $10.1073 /$ pnas. 1616913114

56. Matt KS, Steger RW, Schwabl H, Schwabl I, Moore MC, Farner DS. Neuroendocrine regulation of gonadotropin secretion in Zonotrichia leucophrys gambelii. J Steroid Biochem. (1984) 20:1562.

57. Pratt BL, Takahashi JS. Alpha-2 adrenergic regulation of melatonin release in chick pineal cell cultures. J. Neurosci. (1967) 7:3665-74.

Conflict of Interest Statement: The authors declare that the research was conducted in the absence of any commercial or financial relationships that could be construed as a potential conflict of interest.

Copyright (C) 2019 Tobari and Tsutsui. This is an open-access article distributed under the terms of the Creative Commons Attribution License (CC BY). The use, distribution or reproduction in other forums is permitted, provided the original author(s) and the copyright owner(s) are credited and that the original publication in this journal is cited, in accordance with accepted academic practice. No use, distribution or reproduction is permitted which does not comply with these terms. 